J. Clin. Chem. Clin. Biochem.

Vol. 15, 1977, pp. 297-301

\title{
Evaluation of and Additional Data on an Improved Simple Charcoal Method to Determine Oestrogen Receptors
}

\author{
By C. B. Korsten and J. P. Persijn
}

From the Department of Clinical Chemistry (Head Dr. J. P. Persijn), Antoni van Leeuwenhoek Ziekenhuis, Amsterdam

(Received September 29/December 27, 1976)

Summary: Additional information and some modifications of an earlier published method ((1972) Z. Klin. Chem. $\mathrm{Klin}$. Biochem., 10, 502-508) for the assay of oestrogen receptor in human breast tumours are presented. The correlation between the results obtained with this method and with the electrophoresis procedure of Wagner ((1972) Hoppe Seyler's Z. Physiol. Chem., 353, 1235-1245) was found to be good. The use of glycerol stabilized calf uterus extract for quality control is proposed. Various factors affecting the assay and the discrimination between receptor positive and receptor negative are critically discussed.

\section{Kritische Bewertung einer Methode zur Bestimmung von Oestrogenrezeptoren unter Benutzung von Aktivkohle}

Zusammenfassung: Erweiterte Informationen und einige Änderungen einer früher publizierten Methode ((1972) Z. $\mathrm{Klin}$. Chem. Klin. Biochem., 10, 502-508) zur Bestimmung des Oestrogen-Rezeptors in menschlichen Mammatumoren werden beschrieben. Die Methode zeigt eine gute Korrelation mit Wagner's Methode ((1972) Hoppe-Seyler's Z. Physiol. Chem., 353, 1235-1245), welche die Elektrophorese benutzt. Die Anwendung von mit Glycerin stabilisierten Extrakten von Kalbsuterus für die Qualitätskontrolle wird vorgeschlagen. Verschiedene Faktoren, welche die Bestimmung und die Festlegung der Grenzwerte beeinflussen, werden diskutiert.

\section{Introduction}

The in-vitro assay of oestrogen receptors in human breast cancer tumour tissue is based on the binding of tritiated oestradiol-17- $\beta$ by an extract from a tumour biopsy. There are several methods for the separation and quantitation of receptor-bound oestradiol. Of these, the electrophoretic procedure (1) and some charcoal procedures (2-8) are the most widely used.

In 1972 we introduced a simple charcoal method. We have since been confronted with a number of questions concerning discrimination of "receptor-positive" from "receptor-negative" tumours, routine control of the assay, equivalence of the results obtained by the electrophoretic method and by our charcoal method, etc. This paper is an attempt to provide answers to these questions.

\section{Materials}

Tritium labeled oestradiol-17- $\beta$, labeled in the 6,7 positions with an activity of about $1,48 \mathrm{~TB} \mathrm{q} / \mathrm{mmol}(40 \mathrm{Ci} /$ mmol) was obtained from the Radiochemical Centre,
Amersham, England. Upjohn 11,100 or nafoxidine (1-[2-[p-(3.4-dihydro-6-methoxy-2-phenyl-1-naphthyl) phenoxy] -ethyl] pyrrolidine $\mathrm{HCl}$ ) was a gift from the Upjohn Company, Rijswijk, Holland. Charcoal was obtained from British Drug Houses, England (cat. No. 33032).

Biopsies from metastases were freed from fat as completely as possible and were stored within 15 minutes at $-70^{\circ} \mathrm{C}$ until assay.

Uteri obtained from calves were chilled in ice immediately after slaughtering. Within two hours they were freed from connective tissue, cut into pieces and stored at $-70^{\circ} \mathrm{C}$.

\section{Methods}

Reagents (charcoal assay)

All reagents should be stored at $4{ }^{\circ} \mathrm{C}$.

Tris buffers

Buffer A contains dipotassium ethylene dinitrilo tetraacetate $(1.5 \mathrm{mmol} / \mathrm{l})$ and sodium azide $(1 \mathrm{mmol} / \mathrm{l})$ in Tris buffer (10 mmol/l).

Buffer B contains sucrose $(250 \mathrm{mmol} / \mathrm{l})$ in buffer $A$. 
Dextran coated charcoal

Dissolve $50 \mathrm{mg}$ Dextran 10 (Pharmacia) and $100 \mathrm{mg}$ gelatine in $100 \mathrm{ml}$ buffer B by gently heating up to $60^{\circ} \mathrm{C}$. After cooling $500 \mathrm{mg}$ charcoal is added. The mixture is kept at $4{ }^{\circ} \mathrm{C}$ and discarded after 1 month.

Aliquots should be taken while stirring.

Upjohn 11,100

Dissolve $5.0 \mathrm{mg}$ in $100 \mathrm{ml}$ ethanol analytical grade.

\section{Labeled oestradiol solutions}

Stock solution is diluted with ethanol to a concentration of $200 \mathrm{nmol} / 1$ (stable for 3 months). Twenty fold dilution with buffer $B$ gives the working solution ( $10 \mathrm{nmol} / \mathrm{l})$.

\section{Preparation of extracts}

Homogenization was done as recommended at the E.O.R.T.C. workshop on September 29, 1972 (9). The "microdismembrator" (Braun, Melsungen, Germany) used for the pulverization of the frozen tissue allows maximal extraction of the receptor protein (10). The powdered tissue, still frozen, was dissolved in about two volumes (by weight) of cold $\left(4^{\circ} \mathrm{C}\right)$ buffer $A$. The mixture was spun at $2-4^{\circ} \mathrm{C}$ for 60 minutes at $100,000 \mathrm{~g}$ (Spinco, S.W., 50.1; $2 \mathrm{ml}$ cellulose nitrate reduction tubes). Then, the supernatant was filtered (Schleicher and Schüll 589/2 SS) at $4{ }^{\circ} \mathrm{C}$ to remove the fatty layer on top. Oil-free scissors were used to cut the filter paper to a diameter of $5 \mathrm{~cm}$. Glass tubes were used for keeping the homogenates. Assays were performed immediately following the preparation of the filtered supernatant.

\section{Assays}

\section{The electrophoretic method}

This method has been described fully by Wagner (1). Receptor concentrations were related to tissue protein as proposed by Wagner (1).

\section{The charcoal method}

The assay was performed according to reference 8 . Several modifications have since been introduced, so that it is necessary to describe the whole procedure. As a control, the assay uses Upjohn 11,100 (nafoxidine) which specifically inhibits the binding of oestradiol to the receptor. Receptor concentrations were calculated in terms of Bequerels $\left(\mathrm{s}^{-1}\right)$ per gram total protein.

Procedure

The procedure for the charcoal assay is outlined in table 1. Quench correction is determined for each sample since values may deviate significantly from the quenching by the counting fluid (Instagel).
Calculation

$$
\frac{\text { counts } / \mathrm{min}}{\text { protein }(\mathrm{g} / \mathrm{l})} \times \frac{4.2 \times 10^{6}}{\text { counting efficiency (\%) }} \times \frac{1}{60}=\mathrm{Bq} / \mathrm{g}
$$

counts/min is difference between the counts per minute "total bound" and "Upjohn 11,100 bound".

The factor

$$
\begin{array}{ll}
\frac{4.2 \times 10^{6}}{\text { efficiency (\%) }}= & \frac{2.1 \times 20,000 \times 100}{\text { efficiency }(\%)} \text { is derived from } \\
2.1 & \begin{array}{l}
\text { to calculate total radioactivity of the } \\
\text { mixture }
\end{array} \\
& : \text { activity expressed per litre extract } \\
\frac{20,000}{100} & : \text { converts this to dpm } \\
\text { efficiency (\%) } & : \text { converts this to } \mathrm{Bq}\left(\mathrm{s}^{-1}\right)
\end{array}
$$

Classification of receptor-negative tumours.

For statistical evaluation at least 15 benign human tumours should be assayed by the above technique. A sufficient number of malignant tumours should be also assayed, to include at least eight with apparently higher binding capacities than the benign. The results from benign and malignant tumours are expressed graphically with the probability function $2 \mathrm{n}-1$ on the abcissa

$$
2 \mathrm{~N}
$$

and $\mathrm{Bq} / \mathrm{g}$ protein on the ordinate. The value of $\mathrm{n}$ is the ranking order of the specimens with the lowest activity assigned the value of 1 and $\mathrm{N}$ is equal to the total number of specimens. The probability can be found from a table or by using a linear-probit paper. For an example see reference 11. Connection of the inserted points produces two straight lines. The highest value (Bq/g protein) of the benign tumour which lies on the straight line is still considered to be receptor-negative (or borderline value), but higher values are taken as receptor-positive.

Allowable väriation between duplicates Incubations with $\left[{ }^{3} \mathrm{H}\right.$ ]oestradiol and Upjohn 11,100 were run in duplicate. For different ranges the standard deviation was calculated according to s. $d .=\sqrt{\frac{\sum\left(\dot{d}^{2}\right)}{2 n}}(12)$, where $d$ is the difference between duplicates, $n=$ number of specimens (usually about twenty). Coefficients of variation (C. V.) were calculated according to C. V. $=\frac{100 \times \text { s. } d .}{\bar{x}}$ where $\bar{x}$ is the mean of the values found within a given range. The result of the assay was accepted only if the duplicates deviated from one another by less than $3.2 \times$ C. V. percent.

Tab. 1. Procedure for measurement of oestrogen receptor.

All oestradiol containing solutions and pipettings of oestradiol or Upjohn 11,100 should be stored in or performed with glass ware. All handlings at $4{ }^{\circ} \mathrm{C}$.

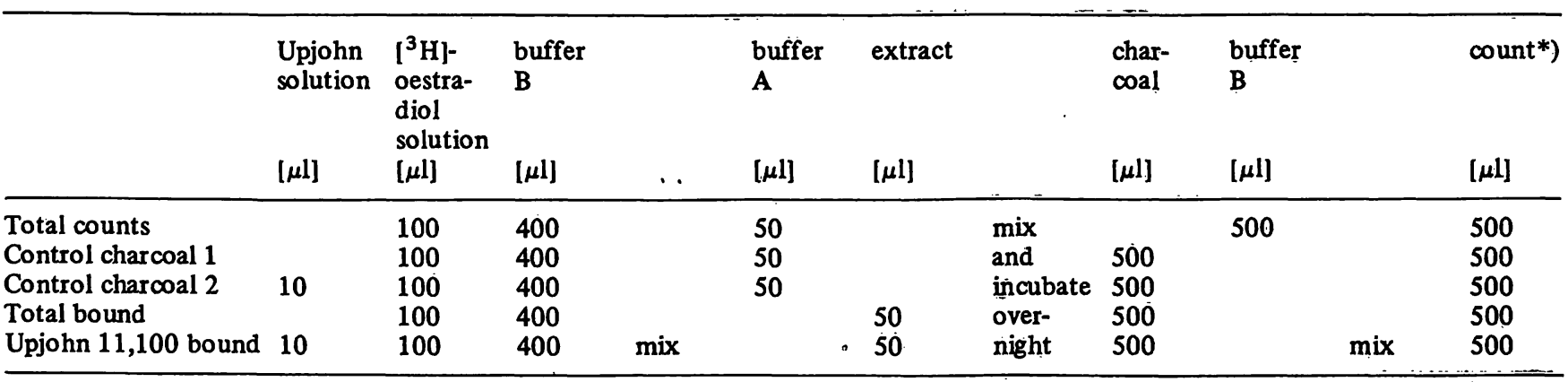

*) After three intermittent shakings for 10 seconds every 3 minutes. 


\section{Total protein}

We use the biuret method with a reaction mixture of $0.05 \mathrm{ml}$ extract and $2 \mathrm{ml}$ biuret reagent. $\mathrm{CuSO}_{4}$ is omitted from the blanks.

\section{Results}

\section{Conditions of incubation}

The time course of the binding of oestradiol at $4{ }^{\circ} \mathrm{C}$ under conditions as described in ref. (8) is shown in figure 1.

Incubation can be restricted to 2 hours if one wishes to speed up the performance of the assay. In ref. (8) a 10-minute charcoal incubation at $4{ }^{\circ} \mathrm{C}$ was recommended. The effects of intermittent shaking for 10 seconds at 3-minute intervals were compared with those of continuous shaking. The result of the assay was not affected by intermittent shaking even if contact with charcoal was extended to 90 minutes. Continuous shaking, however, reduced the difference in net radioactivity between the supernatants of the tubes with and without nafoxidine. A 60-minute period of continuous shaking reduced receptor-bound oestradiol by $20 \%$.

\section{Comparative studies}

Thirty-seven tumours were simultaneously assayed for receptor content by the electrophoretic method and the charcoal method. To exclude heterogeneity, the material to be studied was not split up until after homogenization and centrifugation. The results of the latter method were plotted according to probit analysis (fig. 2). Figure 2 shows two groups with different Gaussian distribution curves: one group comprises all benign tumours and the malignant tumours defined as receptornegative and the other group comprises the tumours shown to be receptor-positive $(8,11)$. Tumours found positive by the electrophoretic method were plotted as solid circles and those found to be receptor-negative as open circles. This makes it possible to compare the two

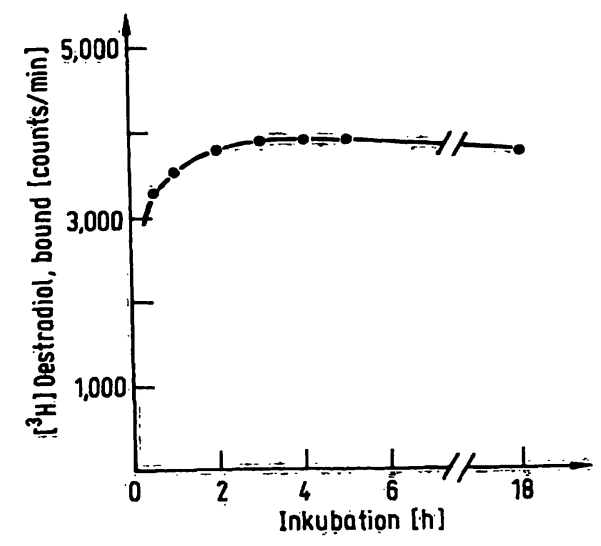

Fig. 1. Time course for the binding of $\left[{ }^{3} \mathrm{H}\right]$ ]oestradiol to receptor in an extract of a human malignant breast tumour.

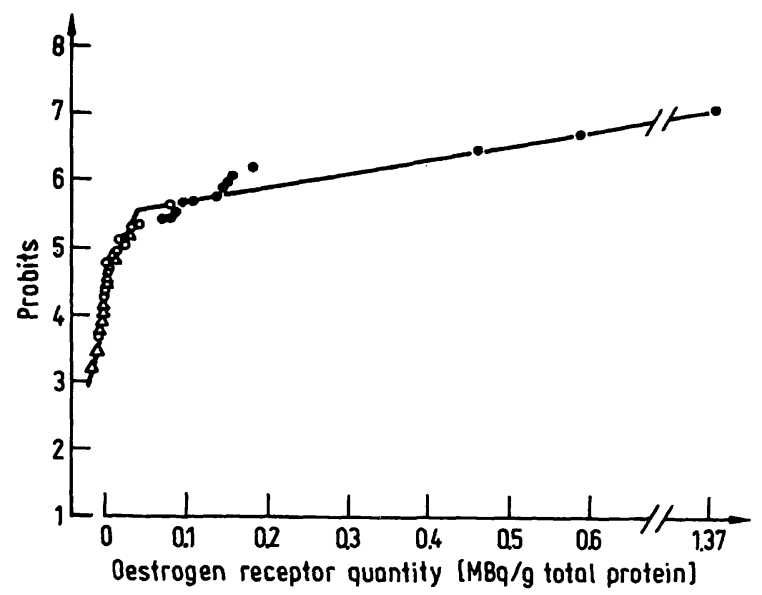

Fig. 2. Probit analysis of oestrogen receptor quantities determined by the charcoal technique described, in malignant (circles) and benign (triangles) human breast tumours. The solid circles represent tumours found to be receptor-positive by the electrophoresis technique; the open circles represent tumours found to be receptor-negative by the electrophoresis technique.

methods. A good correlation is evident in figure 2: only one tumour appeared to be receptor-positive by the electrophoretic method, but receptor-negative by the charcoal method.

\section{Routine control}

The rapid destruction of the receptor during storage in the tumour extract, even at low temperatures $(13,14)$, raises problems in routine control.

In the search of a receptor-containing solution which could serve as a routine control test, results were obtained with calf uterine extract in the presence of glycerol. The underlying idea is that, as for enzymes, glycerol might act as stabilizer for oestrogen receptors. The tissue powder was dissolved in a cooled mixture of Tris buffer und glycerol (volumes, $10 \mathrm{ml}+10 \mathrm{ml}$ ) and the mixture was stored at $-20^{\circ} \mathrm{C}$ after centrifugation. At regular intervals the receptor content was assayed by the charcoal method. The results (fig. 3 ) show that

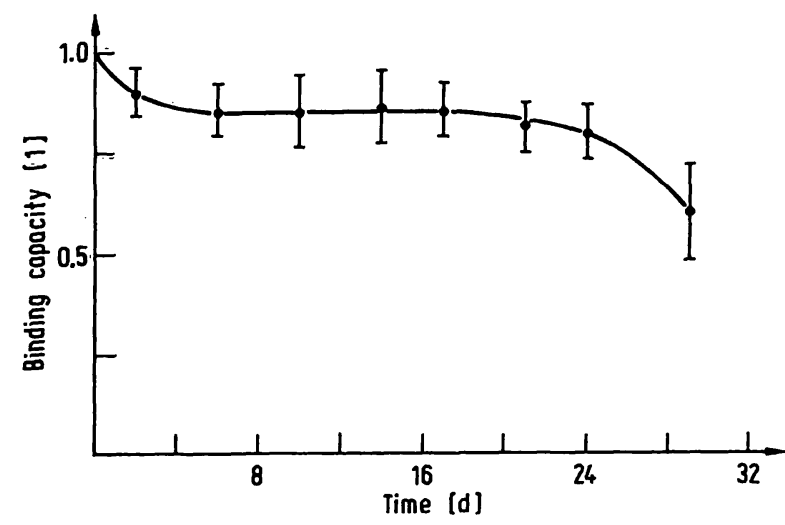

Fig. 3. Binding capacity of calf uterus extract in the presence of glycerol $(1+1$ by volume). The vertical bars indicate maximum and minimum results over six replicates. 
the glycerol-stabilized supernatant can be used as a control for a period of about 3 weeks. More significant loss of binding capacity was found if the mixture was stored at $4{ }^{\circ} \mathrm{C}$. Contrary to Ratajczak \& Hähnel (15) we found that addition of dithioerythritol $(1 \mathrm{mmol} / \mathrm{l})$ was not effective in stabilizing the receptor-binding capacity in calf uterus extract.

\section{Discussion}

Various conditions for incubation with oestrogens or charcoal have been proposed $(1-9,16-19)$ varying from 30 minutes to several hours at temperatures from $4{ }^{\circ} \mathrm{C}$ to $30^{\circ} \mathrm{C}$. However, most relevant reports present no data on the time course. We found the broad binding optimum at $4{ }^{\circ} \mathrm{C}$, unlike to the binding found at higher temperatures (3), to be of advantage for establishing the assay conditions. In incubation with charcoal two processes govern the resulting $\left[{ }^{3} \mathrm{H}\right]$ oestradiol content after separation of the charcoal:

adsorption of unbound and loosely bound oestradiol, and the removal of receptor-bound oestradiol. The latter process is negligible at intermittent shaking for short periods but significantly influences the result of the assay if continuous shaking is applied. We therefore feel that the recommendations of the E.O.R. T.C. workshop (9), specifying continuous shaking for 90 minutes are not meaningful.

The time needed to complete the first process depends on the efficiency of the charcoal batch. Under our conditions of incubation the decrease of radioactivity to a constant level within the first minutes of charcoal treatment is regarded as an indication of sufficient efficiency of the charcoal batch. Occasionally, a large excess of sex hormonale binding globulin may be present in the tumour tested. In such cases a constant level is not reached until after about 10 minutes. The period of contact with the charcoal and the periods of shaking should therefore be timed exactly.

It is now well established that patients suffering from breast cancer with oestrogen receptor-positive metastases have about 60 percent chance of benefitting from hormonal therapy, additive or ablative (20). An explanation for this phenomenon cannot be given. Even more puzzling is the fact that some patients with oestrogen receptor-negative metastases do respond to hormonal therapy $\left.{ }^{1}\right)$. In this respect the criteria for the classification of a tumour in terms of its receptor content are of some

\footnotetext{
1) In our opinion additional assay of other hormone receptors may make it possible to select patients within the oestrogen receptor-negative group who nevertheless respond to hormonal therapy. Preliminary results of androgen receptor assays in premenopausal patients are very promising (21).
}

concern to various authors. Jensen et al (22) retrospectively defined the cut-off level on the basis of the lowest receptor content at which objective remissions were obtained. This theoretically attractive approach has been followed by several authors, but has some drawbacks for the early introduction of a receptor assay in the routine laboratory. Firstly, it requires a long period of clinical experience with a sufficient number of patients showing objective remission. Secondly, modifications to improve the assay technique cannot be introduced during the period of evaluation of the patients. This procedure is even more complicated if different additive therapies are applied. In this respect it should be noted that the highest incidence of responding receptor-negatives seems to occur in therapy with anti-oestrogens (20). In view of the above-mentioned disadvantages it is evident that the procedure to determine the cut-off level should be one that makes it possible to introduce the assay within a short time. We first introduced probit analysis of benign and malignant tumours to establish the discriminating line between receptor-positive and receptor-negative. The results of our clinical studies have proved the correctness of this approach (11) which allows introduction of the receptor assay in the routine laboratory within a short time. In these studies both the charcoal method (with nafoxidine as competitive inhibitor) and the electrophoretic method were applied.

Previous clinical data seemed to indicate the equivalence of both techniques as indicator for hormone responsiveness (11). A compilation of all clinical data we have so far obtained $(11,21)$ gives the figures shown in table 2 . The equivalence of both techniques is evident. The data in figure 2 supply strong additional evidence that either of the two techniques can be used for prediction of the response to endocrine therapy. They also indicate that, for this purpose, it is sufficient to express receptor concentrations in terms of total tumour protein, rather than tissue protein.

The charcoal method described, using nafoxidine as competitive inhibitor, is the simplest and therefore the

Tab. 2. Correlation between presence of oestrogen receptors in 148 patients as determined by different techniques, and response to hormonal therapy. All patients were investigated and followed up according to the criteria outlined in the E.O.R.T.C. Breast Cancer Group protocol (23). In all tissue samples the presence of cancer tissue was verified histologically.

\begin{tabular}{lllll}
\hline & \multicolumn{4}{c}{ No. of patients } \\
\hline Technique & Recep- & Re- & Not re- & Total \\
& tor & sponding & sponding \\
Charcoal & + & 24 & 6 & 30 \\
Electrophoresis & - & 4 & 28 & 32 \\
& + & 23 & 7 & 30 \\
& - & 6 & 50 & 56 \\
\hline
\end{tabular}


most attractive method for the routine laboratory. This method produces data for the therapeutic strategy in breast cancer which are as reliable as those obtained from other but more complicated techniques, e. g. the electrophoretic method.

The use of glycerol-stabilized calf uterus extract is perhaps not ideal, but it is certainly a practical solution to the problem of quality control of oestrogen receptor assays.

\section{Note added to proof:}

Problems in analysis of charcoal method data by Scatchard plot, leading in some cases to mis-classification have been

\section{References}

1. Wagner, R. K. (1972), Hoppe Seylers Z. Physiol. Chem. $353,1235-1245$.

2. Korenman, S. G. \& Dukes, B. A. (1970), J. Clin. Endocrinol. Metab. 30, 639-645.

3. Feherty, P., Farrer-Brown, G. \& Kellie, A. E. (1971), Br. J. Cancer, $X X V, 697-710$.

4. Leung, B. S., Manaugh, L. C. \& Wood, D. C. (1973), Clin. Chim. Acta 46, 69-76.

5. Hahnel, R. \& Twaddle, E. (1971), Steroids 18, 653-680.

6. Hawkins, R. A., Hill, A. \& Freedman, B. (1975), Clin. Chim. Acta 64, 203-210.

7. Johnson, R. B., Nakamura, R. M. \& Libby, R. M. (1975), Clin. Chem. 21, 1725-1730.

8. Korsten, C. B. \& Persijn, J. P. (1972), this J. 10, 502-508.

9. E.O.R.T.C. Breast Cancer Cooperative Group (1973), Europ. J. Cancer 9, 379-381.

10. Wagner, R. K., Personal communication.

11. Korsten, C. B., Engelsman, E. \& Persijn, J. P. (1975) in: Estrogen Receptors in Human Breast Cancer (McGuire, W. L., Carbone, P. P. \& Volmer, E. P., ed.) 93-105, New York, Raven Press.

12. Henry, R. J. \& Dryer, R. L. (1963), Stand. Methods Clin. Chem. 4, 205-237.

13. DeSombre, E. R., Chabaud, J. P., Puca, G. A. \& Jensen, E. V. (1971), J. Stero id Biochem. 2, 95-103.

\section{Acknowledgements}

The authors are indebted to Dr. H. H. Oudshoorn (Ziekenhuis Amsterdam Noord, Amsterdam), Dr. J. A. van der Haar (Onze Lieve Vrouwe Gasthuis, Amsterdam), Dr. H. C. M. van der Schoot (Majella Ziekenhuis, Bussum) and Dr. M. van Wijhe (Majella Ziekenhuis, Bussum) for supplying benign tumours and for the pathological examination of these tumours. The authors gratefully acknowledge the skilful help of Miss $M$. Veen and Mrs. A. C. M. Brakeboer.

This work was supported by a grant from the Maurits and Anna de Kock Fund.

described fully by $H$. Braunsberg (1975), Europ. J. Cancer 11, 499-507.

14. Puca, G. A., Nola, E. Sica, V. \& Bresciani, F. (1972), Biochemistry 11, 4157-4165.

15. Ratajczak, T. \& Hähnel, R. (1974), Biochim. Biophys. Acta 338, 104-107.

16. Hähnel, R. \& Twaddle, E. (1974), J. Steroid Biochem. S, 119-122.

17. McGuire, W. L. (1975), Methods Enzymol. 36, 248-254.

18. Chester, Z., Feherty, P., Kellie, A. E. \& Ralphs, D. N. L. (1975), in: Estrogen Recptors in Human Breast Cancer, (MoGuire, W. L., Carbone, P. P. \& Volmer, E. P., ed.) $157-174$.

19. Maass, H., Engel, B., Hohmeister, H., Lehman, F. \& Trams, G. (1972), Am. J. Obstet. Gynecol. 113, 377-382.

20. Estrogen Receptors in Human Breast Cancer (1975), (McGuire, W. L., Carbone, P. P. \& Vollmer, E. P., ed.), Raven Press, New York.

21. Persijn, J. P., Korsten, C. B. \& Engelsman, E. (1975), Br. Med. J., 503.

22. Jensen, E. V., Polley, T. Z., Smith, S., Block, G. E., Ferguson, D. J. \& DeSombre, E. R. (1975), in: Estrogen Receptors in Human Breast Cancer, (McGuire, W. L., Carbone, P. P. \& Vollmer, E. P., ed.), Raven Press, New York, 37-57. 23. G.E.C.A. (1967), Eur. J. Cancer 2, 201.

Dr. J.-P. Persijn Plesmanlaan 121 Amsterdam Slotervaart 
.

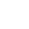

